\title{
ДОСТИЖЕНИЕ УСТОЙЧИВОСТИ НА РЫНКЕ МАТЕРИАЛЬНЫХ РЕСУРСОВ СЕЛЬСКОГО ХОЗЯЙСТВА В КОНТЕКСТЕ РЕСУРСООБЕСПЕЧЕНИЯ
}

\begin{abstract}
C.B. Макрак*
Предложено авторское определение устойчивой ситуации на рынке материальных ресурсов для сельского хозяйства. Проведен мониторинг отдельных показателей состояния рынка материальных ресурсов за период 2000-2019 гг. Выработан комплекс мер и инструментов для достаточного ресурсообеспечения аграрного производства. Раскрыты подходы к формированию механизма функционирования Государственного оператора по поддержке сбалансированного производства сельскохозяйственной продукции; определены способы создания Фонда для поддержки сельскохозяйственных производителей и алгоритмы распределения финансовых средств. Представлена методика оценки устойчивости рынка материальных ресурсов для сельского хозяйства.
\end{abstract}

Ключевые слова: материальные ресурсы, сельское хозяйство, ресурсообеспечение, рынок материальных ресурсов, эффективность, оценка.

JEL-классификация: Q10, Q11, Q12, Q17, Q18.

DOI: $10.46782 / 1818-4510-2021-1-87-100$

Материал поступил 29.09.2020 2.

Ресурсное обеспечение и ресурсопотребление в сельском хозяйстве следует рассматривать как приоритетное направление укрепления и наращивания конкурентоспособного производства, поскольку достаточный уровень материальных ресурсов позволяет произвести, доставить, сохранить и реализовать продукцию в обоснованном количестве, а снижение материальных затрат предопределяет рост эффективности коммерческой деятельности.

Особенностью ресурсопотребления в сельском хозяйстве является то, что определение планируемых уровней материальных ресурсов по их видам и финансовых средств для их приобретения происходит в начале календарного года. Так, использование ресурсов в отрасли растениеводства имеет в основном сезонный характер с учетом технологии возделывания конкретных культур; в отрасли животноводства - связано с особенностями содержания животных, активностью распространения болезней и необ- ходимостью проведения их профилактики. Весьма важным является планирование уровней затрат с учетом возможных изменений конъюнктуры на рынке материальных ресурсов, поскольку, с одной стороны, сравнительно низкие уровни производственных затрат не позволяют в должной мере обеспечить ресурсную составляющую технологического процесса; с другой стороны, сравнительно высокие - снижают ликвидность оборотных средств, тем самым уменьшая инвестиционный потенциал сельского хозяйства; с третьей стороны, прогрессивный рост цен и тарифов на материальные ресурсы не дает возможности произвести в планируемом объеме виды продукции, особо чувствительные к ценовым колебаниям (в 2019 г. к таким культурам нами отнесены картофель и рапс). Многократное повышение цен на отдельные ресурсы в течение календарного периода (при ограниченных финансах) по-разному отражается и на планируемой эффективности использования ма-

* Макрак Светлана Васильевна (makraksv@inbox.ru), кандидат экономических наук, доцент, Институт системных исследований в АПК Национальной академии наук Беларуси (г. Минск, Беларусь). 
териальных ресурсов. Например, в 2019 г. по отношению к предыдущему году вследствие изменения цен и тарифов на них (включая ассортиментные изменения) затраты увеличились по зерновым культурам на 20,5\% (за исключением кукурузы на зерно: затраты снизились на 4,7\%), сахарной свекле - на 14,3\%, картофелю - на 18,3\%, рапсу - на $24,0 \%$, что требовало дополнительных финансовых средств в размере 97, 299, 549 и 154 руб. в расчете 1 гектар соответственно по культурам.

В этой связи важно выявлять и закладывать в программы развития отдельных субъектов хозяйствования, региональные и отраслевые программы риски и угрозы развития рынка материальных ресурсов для сельского хозяйства. Они проявляются в многократном изменении цен и тарифов на ресурсы, включая колебание цен на импортные; в существенном дополнении и изменении нормативной и правовой документации в части приобретения, использования, хранения и утилизации ресурсов; в формировании дефицита отдельных видов материальных ресурсов и др. Необходимо поддерживать устойчивую ситуацию для достаточного ресурсного обеспечения (качественного и своевременного проведения механизированных работ, многократной обработки посевов, досева (пересева) семян и др.) с учетом важности реализации национальной продовольственной безопасности (Алферьев, 2010, 2013; Буць, Таптунов, 2018; Гусаков, 2006, 2013; Гусаков, Шпак, 2018; Киреенко, Горбатовский, Горбатовская, Довнар, 2020; Макрак, 2019; Гракун, 2018) ${ }^{1}$.

Проблематика устойчивости рынка материальных ресурсов для сельского хозяйства является сравнительно новым направлением исследования: с позиции изучения конъюнктуры рынка (включая монопольное положение субъектов хозяйствования) следует отметить работы (Алферьев, Павлова, 2010; Бельский, 2019; Корецкий, 2017; Лукашев, 2009; 2019; Маслова, Чекалин, Авдеев, 2019)²;

1 Сайганов А.С., Крылович Т.А., Карпович С.К., Сердюк Т.И., Щербакова Н.В., Швец М.Г., Гракун В.В., Лабушев Н.А., Дрозд Л.Я., Арешко Д.М., Манько Н.Г., Лукашик Т.М., Аленина Л.Г. 2010. Методические рекомендащии по повышению эффективности агрохимического обслуживания сельскохозяйственных организаций и практические аспекты. Минск: Институт системных исследований в АПК НАН Беларуси. с позиции изучения ресурсопользования в отраслях сельского хозяйства - работы В.Г. Гусакова, В.И. Буць, А.П. Шпака, М.К. Жудро, С.А. Константинова, И.И. Ленькова, В.И. Бельского, Я.Н. Бречко, А.В. Горбатовского и др. Вместе с тем данные направления требуют развития в контексте оценки и поддержания устойчивости рынка материальных ресурсов с позиции сбалансированного производства сельскохозяйственной продукции, которое оценивается через параметры производства сельскохозяйственной продукции, достижение планируемых уровней валового производства в разрезе видов сельскохозяйственной продукции с учетом производственно-экономического потенциала регионов страны, включая показатели, заложенные Государственной программой развития аграрного бизнеса в Республике Беларусь на 2016-2020 годы, Доктриной национальной продовольственной безопасности Республики Беларусь до 2030 года ${ }^{3}$. В результате появится возможность своевременно выявлять, оценивать, прогнозировать и упреждать внутренние и внешние угрозы производства отдельных видов продукции уже на стадии разработки бизнес-планов, минимизировать их негативное влияние и др.; обосновать необходимый уровень поддержки сельскохозяйственных производителей, обусловленный изменением конъюнктуры на рынке материальных ресурсов для сельского хозяйства.

Ряд исследователей в рамках теоретико-методологических и практических положений продовольственной безопасности уже обосновали угрозы ее достижения ${ }^{4}$

${ }^{2}$ Урбанская Г.Г. 2003. Принципь организащии и функиионирования рынка материально-технических ресурсов в региональном АПК. Экономика сельского хозяйства: реферативный журнал. № 2. С. 348-350; Быков Г.Е. 2008. Рынок ресурсов для сельского хозяйства. Инженерно-техническое обеспечение АПК: реферативный журнал. № 3. С. 669-701. Макрак С.В. 2014. Снижение материалоемкости сельскохозяйственной продукции: теория и практика. Минск: Институт системных исследований в АПК НАН Беларуси.

3 URL: http://www.government.by/upload/docs/ file27d7ec1a11a991f6.PDF

${ }^{4}$ Ильина 3.М., Шпак А.П., Ломакина А.Л., Бубен С.Б., Байгот Л.Н., Киреенко Н.В., Кондратенко С.А., Тетеркина А.М., Баран Г.А., Бречко Я.Н., Ахрамович В.С., Вероха Л.М., Макуценя Е.П., Гусакова И.В., Енчик Л.Т., Карпович Н.В., Кузьмич Л.И., Лобанова Л.А., Гусаков Г.В. 2014. Продовольственная безопасность Республики Беларусь. Мониторинг-2013: в контексте глобальных проблем в сфере продовольствия. Минск: Институт системных исследований в АПК Национальной академии наук Беларуси. 


\section{Мониторинг рынка материальных ресурсов}

О неустойчивости рынка материальных ресурсов для сельского хозяйства (как по годам, так и по периодам) свидетельствуют результаты мониторинга отдельных показателей, характеризующих его состояние. Если за период 2000-2010 гг. динамика цен на ресурсы промышленного производства для села имела устойчивый прогрессирующий рост (от 56,3\% по бензину до 176 раз по электроэнергии), то за период 2011-
2019 гг. увеличение цен имело нестабильный характер, а по минеральным удобрениям наблюдалось даже снижение (табл. 1). Пропорциональной зависимости изменения цен на внутреннем и зарубежных рынках не установлено. Исследование количественных показателей использования минеральных удобрений, средств защиты растений свидетельствует об отсутствии устойчивого их уровня, вместе с тем расход топливно-энергетических ресурсов имеет существенный уровень снижения (рис. 1-3).

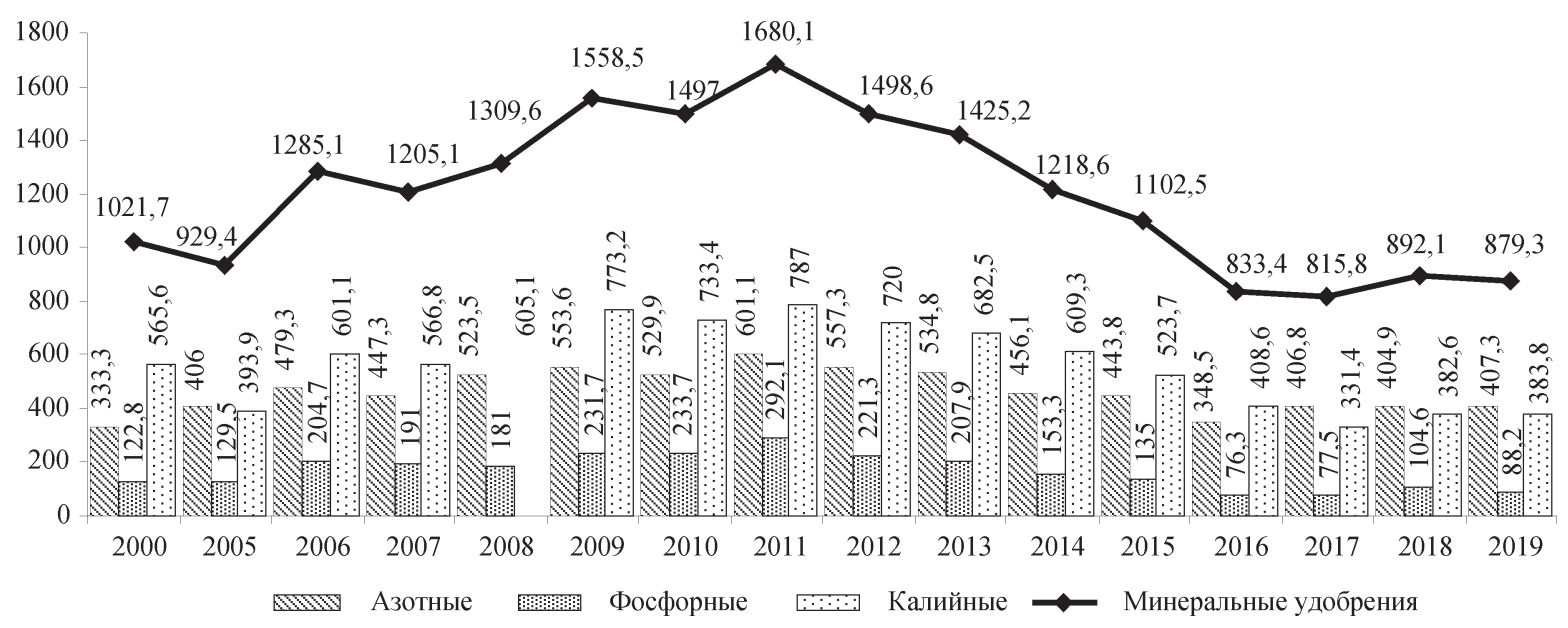

Рис. 1. Динамика внесенных минеральных удобрений под сельскохозяйственные культуры, на сенокосы, пастбища, тыс. т д. в.*

* Действующего вещества.

Источник. Данные Национального статистического комитета Республики Беларусь.

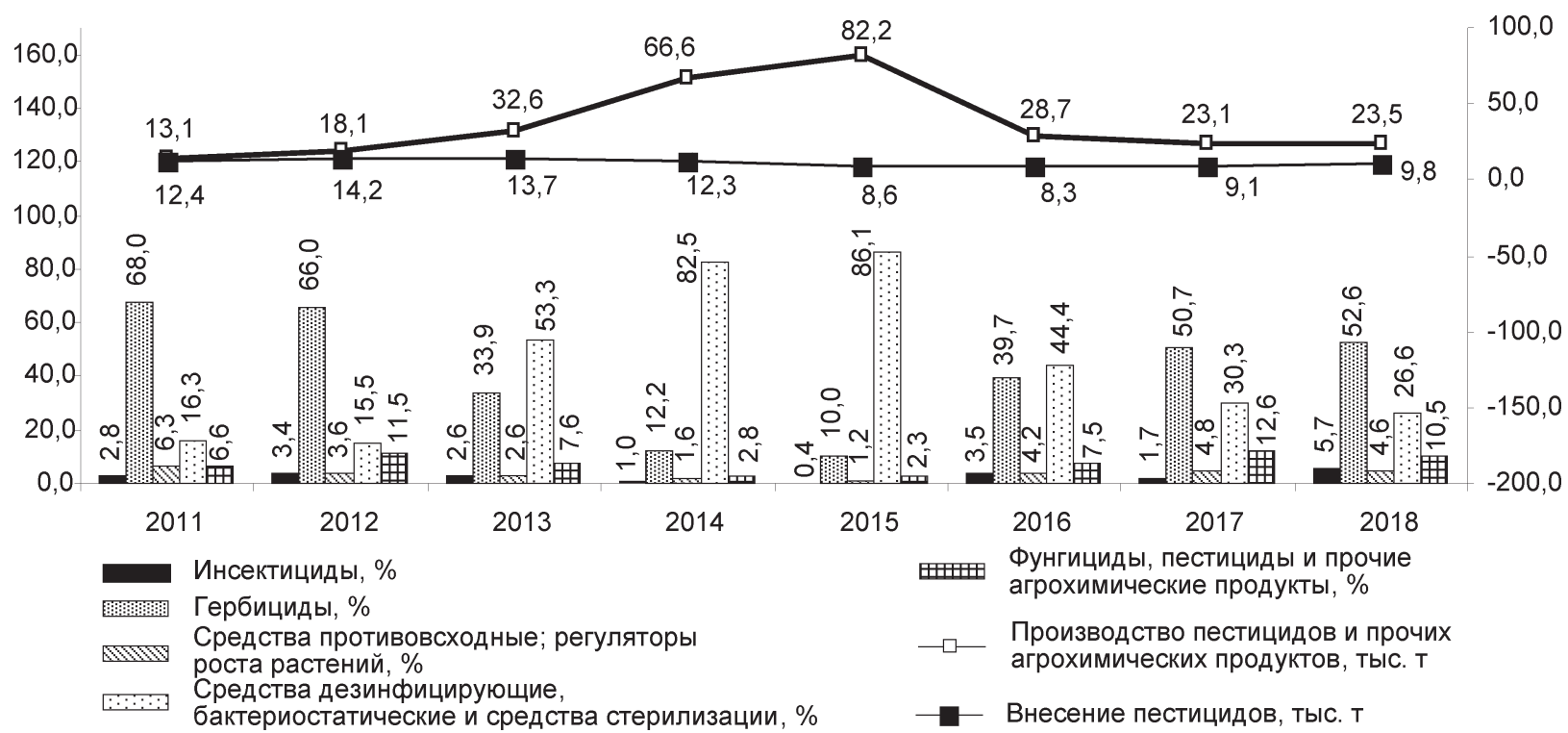

Рис. 2. Динамика объемов и структуры производства агрохимических продуктов, объемов применения средств защиты растений

Источник. Данные Национального статистического комитета Республики Беларусь. 


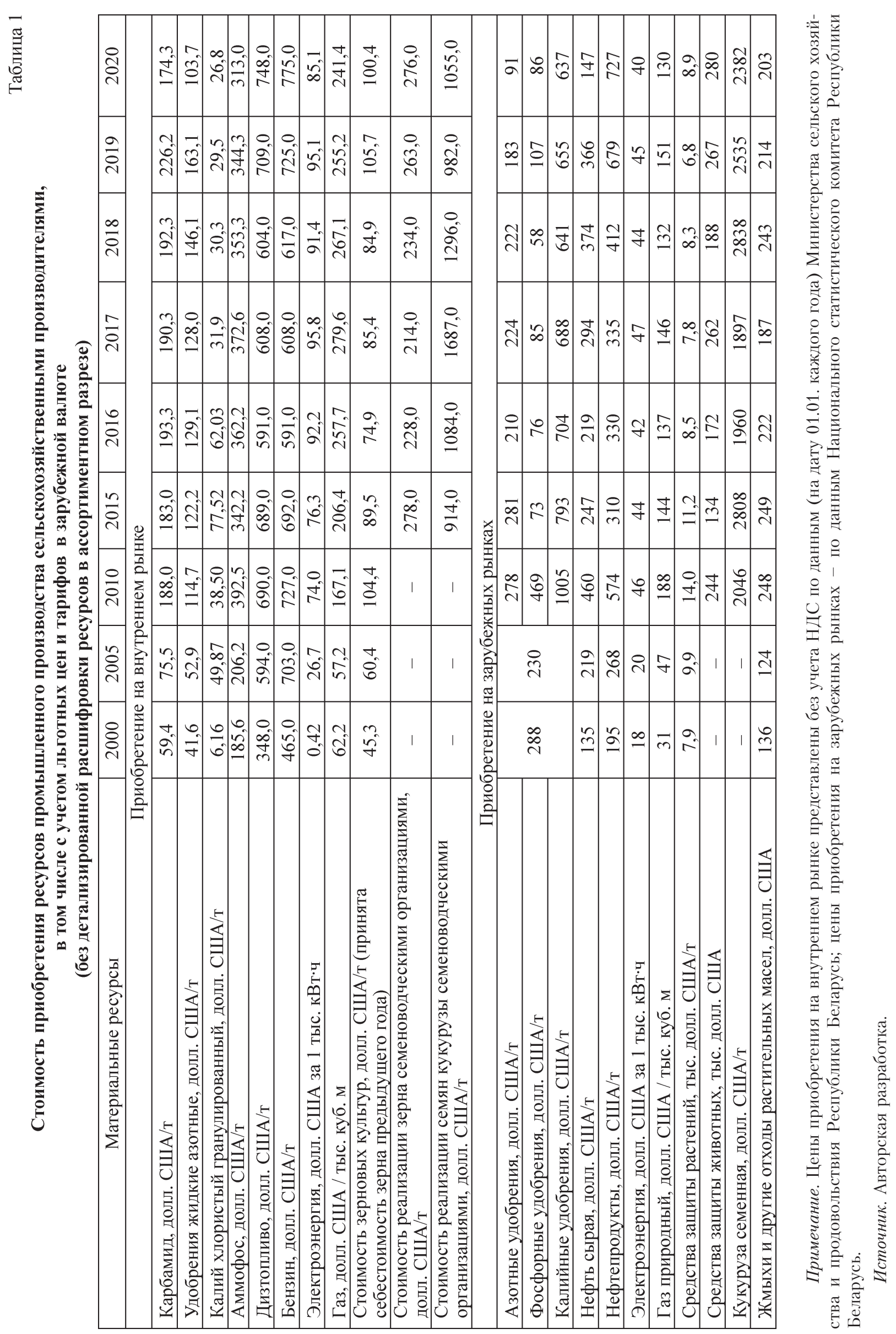




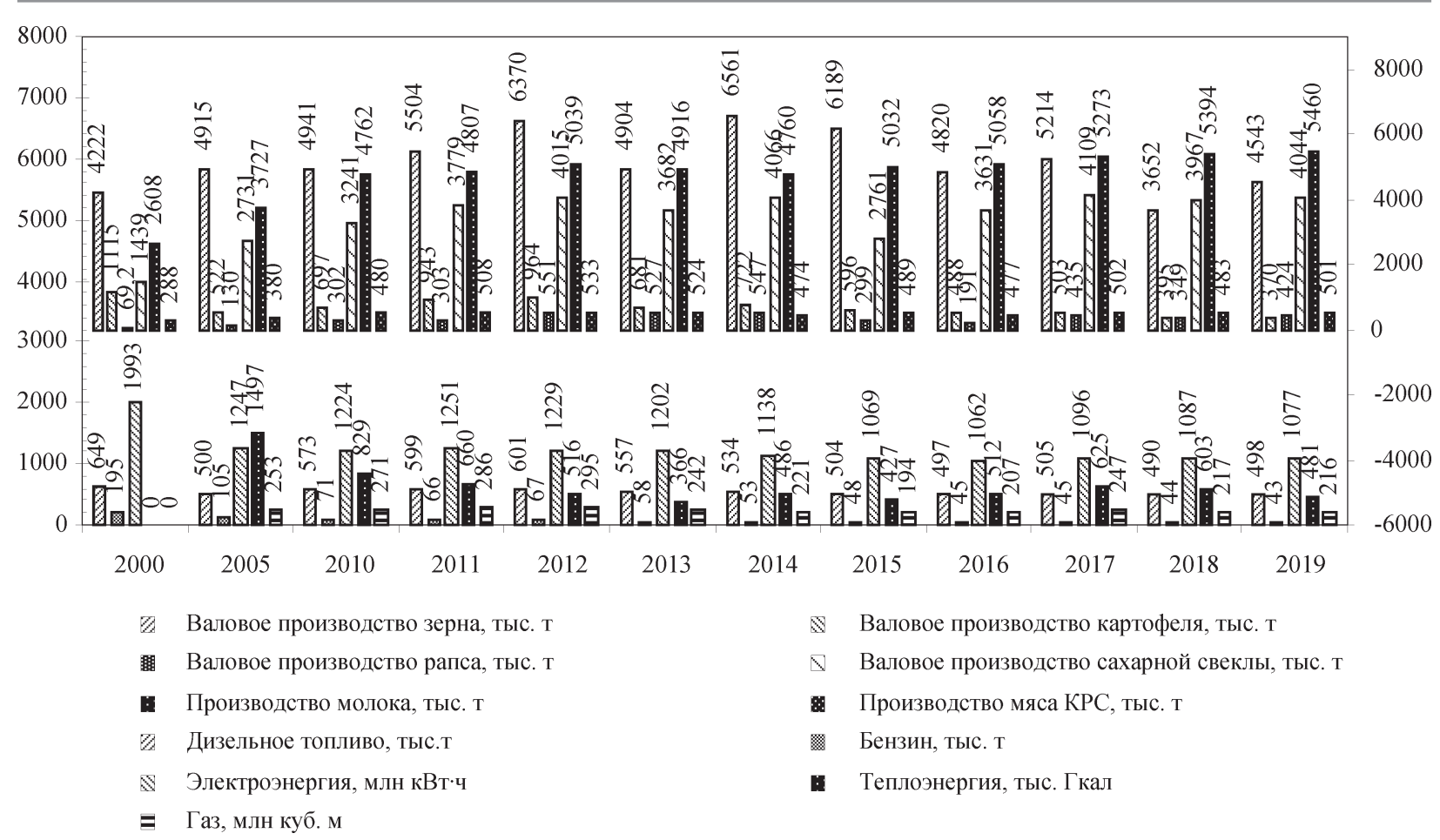

Рис. 3. Динамика использования топливно-энергетических ресурсов в сельскохозяйственных организациях в контексте роста валового производства сельскохозяйственной продукции

Источник. Данные сводных годовых отчетов Министерства сельского хозяйства и продовольствия Республики Беларусь.

За период 2000-2019 гг. величина внесенных минеральных удобрений снизилась: под сельскохозяйственные культуры, на сенокосы, пастбища на 142,4 тыс. т д. в. (или на 16,1\%), с 1021,7 до 879,3 тыс. т д. в.; под сельскохозяйственные культуры - на 24,1 тыс. т д. в. (или на 2,9\%), с 850,3 до 826,2 тыс. т д. в., в том числе в расчете на 1 гектар - на 14,0 кг д. в. (или на 11,7\%), с 134 до 120 кг д. в. Отмечено и пропорциональное изменение видов минеральных удобрений: сократилось потребление фосфорных удобрений на 2,0 п. п., калийных - на 11,8 п. п. Количество вносимых средств защиты растений в сельскохозяйственных организациях за период 2011-2018 гг. снизилось на 2,6 тыс. т, или на $26,5 \%$, с 12,4 до 9,8 тыс. т, в том числе в расчете на 1 гектар пашни - в 1,6 раза, или на 35,8\%, с 2,6 до 1,67 тыс. т (2017 г.). Установлено, что в Республике Беларусь производство агрохимических продуктов (всех их видов) за период 2011-2019 гг. увеличилось на 10,4 тыс. т., или в 1,8 раза, с 13,1 до 23,5 тыс. т, вместе с тем устойчивой динамики роста не наблюдается. При увеличении объемов производства средств защиты рас- тений их доля в общей структуре агрохимических средств уменьшилась на 8,7\%, с 77,4 до $68,7 \%$. Вместе с тем следует отметить, что рынок средств защиты растений достаточно устойчив по показателям производственноресурсной группы. В сельскохозяйственных организациях за период 2000-2019 гг. снизился расход по следующим видам энергетических ресурсов: дизельное топливо - в 1,3 раза, с 649 до 498 тыс. т; бензин - в 4,6 раза, со 195 до 42,8 тыс. т; электроэнергии в 1,9 раза, с 1993 до 1077 млн кВт.ч при увеличении валового производства практически всех видов продукции сельскохозяйственной продукции. Вместе с тем высокий уровень материальных затрат (порядка 3,5 млрд долл. США), сравнительно низкие уровни снижения материалоемкости сельскохозяйственной продукции (табл. 2) требуют развития научно-практических подходов в части ресурсообеспечения для роста эффективности и конкурентоспособности сельскохозяйственной продукции и достижения продовольственной безопасности с учетом конъюнктуры рынка материальных ресурсов для сельского хозяйства через установление 
Динамика показателей оценки использования материальных ресурсов в сельскохозяйственных организациях Республики Беларусь

\begin{tabular}{|l|c|c|c|c|c|c|c|c|}
\hline \multicolumn{1}{|c|}{ Показатель } & 2000 & 2005 & 2010 & 2015 & 2016 & 2017 & 2018 & 2019 \\
\hline $\begin{array}{l}\text { Материальные затраты при производстве } \\
\text { сельскохозяйственной продукции, } \\
\text { млн долл. США }\end{array}$ & 3880 & 2307 & 4616 & 3672 & 3144 & 3580 & 3560 & 3760 \\
\hline $\begin{array}{l}\text { В том числе: } \\
\text { растениеводства }\end{array}$ & 1351 & 769 & 1561 & 1180 & 993 & 1130 & 1048 & 1144 \\
\hline животноводства & 2120 & 1322 & 2613 & 2147 & 1839 & 2095 & 2143 & 2229 \\
\hline $\begin{array}{l}\text { Материалоемкость сельского хозяйства, } \\
\text { долл. США на 1000 долл. США продукции }\end{array}$ & 2518 & 985 & 1074 & 914 & 719 & 887 & 857 & 839 \\
\hline $\begin{array}{l}\text { В том числе: } \\
\text { растениеводства }\end{array}$ & 1578 & 787 & 938 & 800 & 551 & 721 & 706 & 688 \\
\hline животноводства & 3095 & 969 & 992 & 845 & 716 & 848 & 803 & 791 \\
\hline
\end{tabular}

Источник. Данные сводных годовых отчетов Министерства сельского хозяйства и продовольствия Республики Беларусь.

устойчивой ситуации на рынке материальных ресурсов.

\section{Периоды устойчивости рынка}

В рамках данных исследований нами выделяется три положения устойчивости рынка материальных ресурсов с позиции сбалансированного производства сельскохозяйственной продукции: устойчивая ситуащия, при которой достигается продовольственная безопасность при создании благоприятных условий ресурсообеспечения, включая реализацию расширенного воспроизводства; неустойчивая ситуащия ярко выражены угрозы достижению параметров собственного производства сельскохозяйственной продукции, сырья и продовольствия хотя бы по одному наименованию продукции, что в последующем может спровоцировать уменьшение емкости внутреннего рынка по одним видам продукции и увеличение - по другим; стабилизация рынка материальных ресурсов, при которой сельскохозяйственные производители скорректировали целевые показатели на основании взвешенной оценки сложившейся ситуации на рынке материальных ресурсов и приспособились к ее новым условиям.

Факторы неустойчивости рынка материальных ресурсов для сельского хозяйства: непредвиденные изменения в нормативно-правовой документации в части управления материальными ресурсами (включая раз- меры ставок по краткосрочным кредитам и займам; условия выполнения закупок ресурсов за счет бюджетных и собственных средств; устранение недобросовестной конкуренции; изменение количества субъектов монополистической деятельности и др.);

отсутствие доступа (или временный доступ) к международным и национальным электронным торговым платформам материальных ресурсов;

введение санкций против страны или отдельных поставщиков материальных ресурсов;

рост цен на материальные ресурсы (непредсказуемый, прогрессивный, скачкообразный, волнообразный и др.);

падение предложения на отдельные виды ресурсов;

рост спроса на отдельные виды материальных ресурсов;

влияние финансовых инструментов (курсы валют; размеры ставок по краткосрочным кредитам; суммы дотаций и компенсационных выплат вследствие диспаритета цен на ресурсы промышленного производства и сельскохозяйственную продукцию);

барьеры при приобретении импортных ресурсов, включая их оплату, транспортировку и др.

Одной из задач эффективного управления материальными ресурсами в сельском хозяйстве является предотвращение неустойчивой ситуации на рынке материальных ресурсов или минимизация периода ее продолжительности за счет активизации определен- 
ных инструментов реагирования на изменение рыночной конъюнктуры через выработку инструментов стабилизации и поддержания сельскохозяйственных производителей. Это позволит адаптироваться к новым условиям и стабилизировать бизнес-процессы, ориентированные на достижение продовольственной безопасности, включая устойчивое развитие внутреннего производства основных видов сельскохозяйственной продукции, сырья и продовольствия, достаточного для обеспечения продовольственной независимости и реализации экспортного потенциала АПК.

Как показывают результаты научных публикаций в части управления АПК, включая государственное регулирование, производство агропродукции будет являться прибыльным при централизованной координации отдельных процессов, в том числе связанных с ресурсным обеспечением. На рис. 4 представлена схема реализации устойчивого положения рынка материальных ресурсов для сельского хозяйства, способного сформировать благоприятные конкурентные условия для производителей сельскохозяйственной продукции. Отличительная особенность нашей разработки заключается в детализации области государственного регулирования рынка материальных ресурсов, выявлении и систематизации ряда условий и факторов его саморегулирования (рост платежеспособности сельского хозяйства, инвестиционные вложения в инновационные технологии производства ресурсов и др.), направлений государственного регулирования рынка (обоснование коридоров цен на материальные ресурсы, поддержка и дотации приобретения определенных видов ресурсов, стимулирование реализации партнерских программ и др.) с целью:

эффективного развития рынка материальных ресурсов в условиях достаточной конкуренции;

поддержания видов сельскохозяйственной продукции, наиболее уязвимых к изменению конъюнктуры рынка материальных ресурсов;

реализации действенного комплекса мер и мероприятий по эффективному и конкурентоспособному производству сельскохозяйственной продукции.

\section{Инструменты стабилизации рынка}

В исследованиях по проблеме поддержания доходности сельскохозяйственных производителей, в том числе через инструменты государственного регулирования, предлагается: выделение отдельного субъекта хозяйствования (агента, оператора) с частью функций по организации и ведению процесса проведения закупочных и товарных интервенций сельскохозяйственной продукции; создание республиканского интервенционного фонда сельскохозяйственной продукции, сырья и продовольствия; оказание поддержки сельскохозяйственным товаропроизводителям, условием предоставления которой является использование в процессе производства отечественных товаров вместо ввозимых (импортируемых). Такое требование может выражаться как в установлении номенклатуры поставщиков и ресурсов, так и критериев, которые включают получение субсидий и использование товаров отечественного производства (Гусаков, 2006; Шпак, 2017, 2018; Бельский, 2019; Тетеркина, Строгий, 2017; Казакевич, Лазаревич, 2018; Мальцева, 2015; Лазаревич, Микулич, Тетеркина, Пашкевич, Антонова, 2018). В развитие этих исследований считаем целесообразным создание отдельной структуры по поддержанию сбалансированного производства сельскохозяйственной продукции с учетом разных уровней устойчивости развития рьюка материальных ресурсов (в лище государственного оператора), регулирующей и стабилизирующей ситуацию на рынке материальных ресурсов, что выгодно как сельскохозяйственным производителям, так и другим субъектам национальной экономики (рис. 5). Лучше всего, если на первоначальном этапе функцию создания данной структуры возьмет на себя государство в качестве Государственного оператора (на период оценки целесообразности ее функционирования по поддержанию сбалансированного производства сельскохозяйственной продукции с учетом разных уровней устойчивости развития рынка материальных ресурсов). В последующем область данной компетенции (или отдельные функции и задачи) перейдет в Координирующий союз взаимодействия всех субъектов АПК (производители сельскохозяйственной продук- 


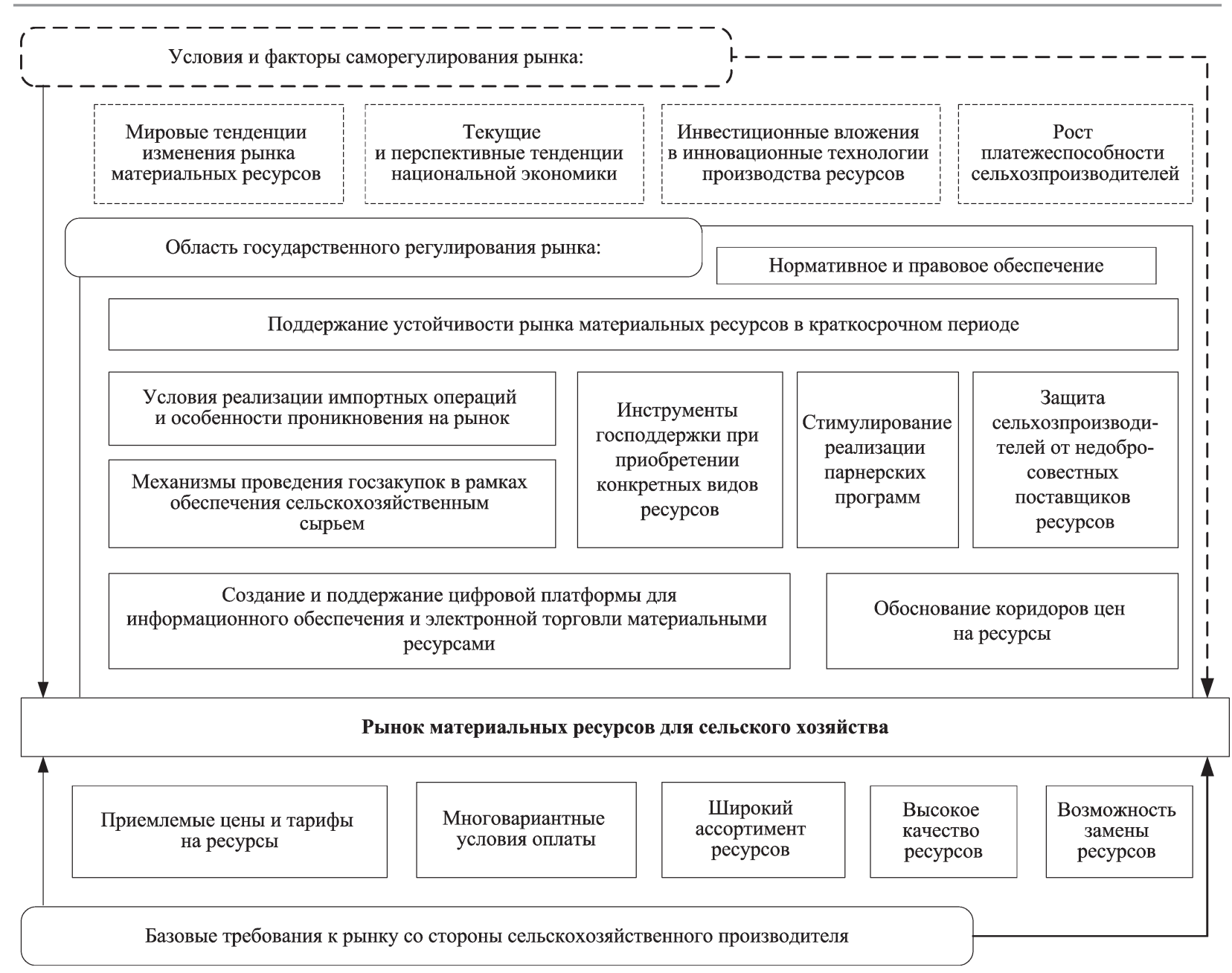

Рис. 4. Схема реализации устойчивого положения рынка материальных ресурсов с позиции активизации инструментов государственного регулирования

Источник. Авторская разработка.

ции, организации пищевой промышленности и торговли, финансовые институты и логистические центры).

В отличие от уже существующих подходов по обеспечению доходности сельскохозяйственных производителей, представленная нами разработка, во-первых, ориентирована на исследование и оценку конъюнктуры рынка материальных ресурсов для сельского хозяйства, поддержание его устойчивости с позиции благоприятных условий ресурсообеспечения (не затрагивая процессы реализации сельскохозяйственной продукции и механизмы ее ценообразования); во-вторых, включает обоснование целесообразности взаимодействия всех субъектов АПК (включая не только организации пищевой промышленности и торговли, но и финансовые институты) с позиции последующей реализации ими хо- зяйственной деятельности; в-третьих, содержит подходы к взаимодействию субъектов хозяйствования в условиях нестабильности ресурсопотребления; в-четвертых, конкретизирует основные функции Государственного оператора по поддержке сбалансированного производства сельскохозяйственной продукции в рамках достаточного ресурсообеспечения. Результаты исследований будут полезными при освоении более эффективных инструментов планирования, формировании долгосрочных контрактов на поставку ресурсов при минимизации рисков (как роста, так и падения цен на материальные ресурсы); с целью поддержания благоприятных условий производства сельскохозяйственной продукции в долгосрочной перспективе, развития защитных механизмов производителей сельскохозяйственной продукции и др. 


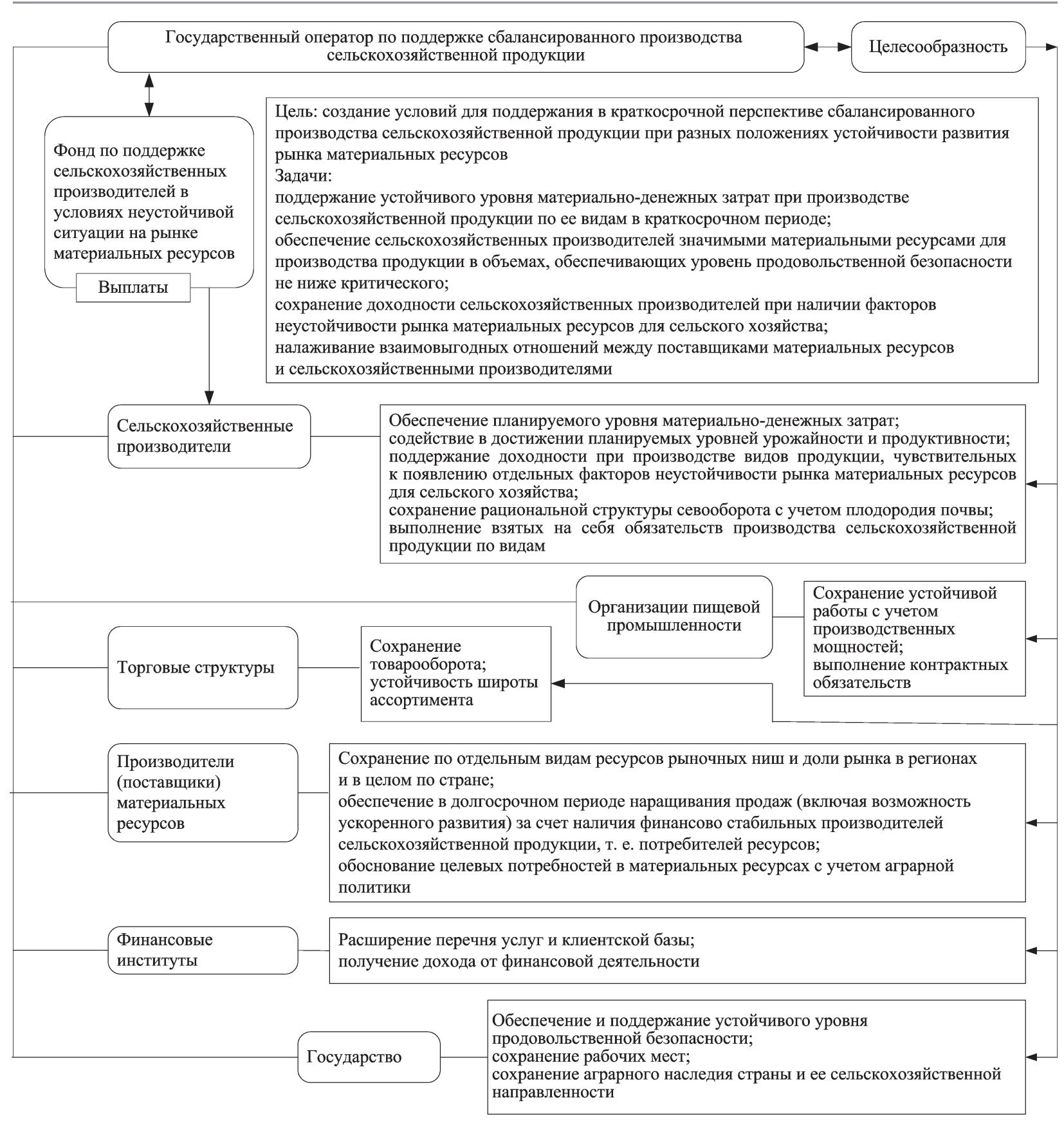

Рис. 5. Подходы к формированию механизма функционирования Государственного оператора по поддержке сбалансированного производства сельскохозяйственной продукции

Источник. Авторская разработка.

Вместе с тем ошибочно полагать, что в стране должна искусственно поддерживаться устойчивость рынка материальных ресурсов. Основной целью Государственного оператора по поддержке сбалансированного производства сельскохозяйственной продукции при разных положениях устойчивости этого рынка является сглаживание резких его колебаний для сельского хозяйства с целью производства продукции в количестве, дос- таточном для достижения продовольственной безопасности, а также поддержка производителей продукции, особо чувствительной к ценовым колебаниям. Следует подчеркнуть, что активность должна характеризироваться параллельным (стимулирующим, подтягивающим) развитием отраслей агрохимической промышленности и сельского хозяйства. В связи с этим в условиях формирования партнерских отношений, в том числе за счет ак- 
тивизации и освоения инструментов цифровой экономики, устраняющей территориальные границы взаимодействия поставщиков материальных ресурсов и сельскохозяйственных производителей, требуется создание качественно новой согласованной модели ведения бизнеса в сельском хозяйстве, где каждый участник будет заинтересован в прибыли своего партнера, и в первую очередь эффективности сельскохозяйственной деятельности. В данном случае Государственный оператор может быть преобразован в Координирующий союз.

На наш взгляд, основными функциями Государственного оператора по поддержке сбалансированного производства сельскохозяйственной продукции через достаточное ресурсообеспечение могут быть:

мониторинг мировой ситуации на рынке материальных ресурсов для сельского хозяйства, включая цены и тарифы, планируемое количество добычи, производства, реализации в разрезе стран;

информирование сельскохозяйственных производителей об угрозах и возможностях развития рынка материальных ресурсов (международного, межрегионального, национального, регионального) в долгосрочной и краткосрочной перспективе;

разработка, согласование и утверждение совместно с профильными ведомствами внешнеэкономической политики и ее инструментов применительно к материальным ресурсам для сельского хозяйства;

сотрудничество с Министерством антимонопольного регулирования и торговли Республики Беларусь в контексте поддержания благоприятной конкурентной среды развития рынка материальных ресурсов для сельского хозяйства;

разработка и предложение методик и рекомендаций по определению компенсационных выплат, дотаций и иной помощи сельскохозяйственным производителям с учетом чувствительности к ценовым колебаниям производимой ими продукции;

обоснование и содействие в продвижении партнерских программ поставщиков материальных ресурсов и производителей сельскохозяйственной продукции, которые будут реализовываться в условиях неустойчивого развития рынка материальных ресурсов; формирование резервных фондов материальных ресурсов (в частности, семян овощных культур, сахарной свеклы, фосфорных удобрений и др.), которые импортируются в страну, в количестве, необходимом для производства сельскохозяйственной продукции по видам для поддержания продовольственной безопасности;

поиск поставщиков материальных ресурсов, которые готовы и имеют возможность поддержать сельскохозяйственных производителей в случае неустойчивой ситуации на рынке;

формирование фондов для поддержки сельскохозяйственных производителей в условиях разных периодов устойчивости на рынке материальных ресурсов, включая резкие непредсказуемые скачки цен на определенные виды ресурсов и др. Установлено, что основными источниками формирования таких фондов будут являться отчисления по субъектам хозяйствования (их выбор был реализован на основании процессно-функционального подхода) с позиции возможности и результативности реализации их деятельности. В виде обязательных отчислений данные средства будут перенаправляться Государственному оператору по поддержке сбалансированного производства сельскохозяйственной продукции.

\section{Подготовка устойчивости рынка материальных ресурсов для сельхозпроизводителй}

Нами предложен следующий алгоритм формирования Фонда для достаточного ресурсообеспечения: 1) выбор показателей, уровень которых будет являться базой для отчислений, с учетом детализации субъектов хозяйствования по видам реализуемой ими деятельности; 2) определение процента отчислений с учетом причастности к рынку материальных ресурсов, но не более 1,5\%. Сумма Фонда, предназначенная для поддержания в долгосрочной перспективе сбалансированного производства сельскохозяйственной продукции при разных положениях устойчивости развития рынка материальных ресурсов, может составить 116,6 млн долл. США (табл. 3). При этом в условиях устойчивости рынка данные денежные средства могут возвращаться 
Алгоритм формирования Фонда для поддержки сельскохозяйственных производителей при неустойчивой ситуации на рынке материальных ресурсов

\begin{tabular}{|c|c|c|c|c|}
\hline $\begin{array}{c}\text { Субъект } \\
\text { хозяйствования }\end{array}$ & Источник отчислений & $\begin{array}{l}\text { Отчисле- } \\
\text { ния, \% }\end{array}$ & $\begin{array}{l}\text { Среднее значение } \\
\text { за 2017-2018 гг., } \\
\text { млн долл. США }\end{array}$ & $\begin{array}{l}\text { Расчет суммы, } \\
\text { млн долл. США }\end{array}$ \\
\hline П. 1 & п. 2 & п. 3 & п. 4 & $\begin{array}{c}\text { П. } 5= \\
=\text { П. } 3 \text { х П. } 4 / 100\end{array}$ \\
\hline $\begin{array}{l}\text { Сельскохозяй- } \\
\text { ственные } \\
\text { производители }\end{array}$ & $\begin{array}{l}\text { Прибыль от реализации продукции } \\
\text { с учетом доли материальных затрат } \\
\text { в себестоимости продукции }\end{array}$ & 1,0 & 290 & 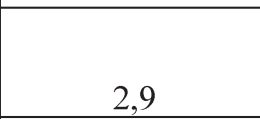 \\
\hline $\begin{array}{l}\text { Организации } \\
\text { пищевой } \\
\text { промышленности }\end{array}$ & $\begin{array}{l}\text { Прибыль от реализации } \\
\text { организаций }\end{array}$ & 1,0 & 1058 & 10,6 \\
\hline \multirow[t]{3}{*}{$\begin{array}{l}\text { Торговые } \\
\text { структуры }\end{array}$} & \begin{tabular}{|l} 
Розничный оборот \\
продовольственных товаров
\end{tabular} & 0,5 & 10718 & 53,5 \\
\hline & Оптовый товарооборот & 0,5 & 4154 & 20,8 \\
\hline & $\begin{array}{l}\text { Биржевой оборот } \\
\text { сельскохозяйственной продукции }\end{array}$ & 0,5 & 359 & 1,8 \\
\hline $\begin{array}{l}\text { Поставщики } \\
\text { материальных } \\
\text { ресурсов }\end{array}$ & $\begin{array}{l}\text { Уровень материальных затрат } \\
\text { с учетом затрат на транспортировку } \\
\text { (ориентировочно } 30 \% \text { ) }\end{array}$ & 1,0 & 2499 & 25,0 \\
\hline $\begin{array}{l}\text { Банковские } \\
\text { структуры }\end{array}$ & $\begin{array}{l}\text { Краткосрочные кредиты и займы, } \\
\text { выданные сельскохозяйственным } \\
\text { производителям }\end{array}$ & 1,0 & 201 & 2,0 \\
\hline \multicolumn{4}{|l|}{ Итого } & 116,6 \\
\hline
\end{tabular}

Источник. Данные Национального статистического комитета Республики Беларусь и сводных годовых отчетов Министерства сельского хозяйства и продовольствия Республики Беларусь.

субъектам хозяйствования или частично переходить на следующий год и использоваться в случае неустойчивости рынка.

На следующем этапе проведения исследований для определения уровней устойчивости рынка нами предлагается методика оценки устойчивости рынка материальных ресурсов сельского хозяйства в разрезе их видов с учетом изменения рыночной коньюнктуры. Она включает следующие основные элементы:

- определение показателей устойчивости рынка материальных ресурсов для сельского хозяйства с учетом изменения рыночной конъюнктуры, детализированных по группам (общая импортная группа, внешнеэкономическая, нормативная и правовая, ресурсно-производственная, финансовая);

- составление алгоритма расчета коэффициентов устойчивости рынка материальных ресурсов на основании конкретного показателя через отклонение от среднего значения;

- установление уровня коэффициентов устойчивости рынка материальных ресурсов (особо устойчивый, сравнительно устойчивый, неустойчивый).
Сущность методики заключается в выявлении наиболее уязвимых мест рынка за счет изменения рыночной конъюнктуры, которые в последующем способны оказать существенное влияние на уровень продовольственной безопасности и ресурсное обеспечение сельскохозяйственных производителей. Практическая значимость методики:

- определение наиболее уязвимых при изменении рыночной конъюнктуры видов сельскохозяйственной продукции в краткосрочном и долгосрочном периодах;

- обоснование целесообразной емкости рынка в разрезе ресурсов отечественного и зарубежного производства;

- определение на краткосрочную и долгосрочную перспективу количественного размера расхода ресурсов в сельском хозяйстве;

- прогнозирование возможных угроз, рисков, кризисов на рынках с целью минимизации их влияния на сельское хозяйство.

Предложенная методика позволяет проводить мониторинг рынка материальных ресурсов за разные периоды времени. Это связано с доступностью данных для анализа и расчетов, разным уровнем значимости ресур- 
сов в производственном процессе, особенностями их приобретения и использования.

По результатам исследований установлено, что ежегодная дополнительная финансовая поддержка должна быть направлена на устойчивое развитие рынка минеральных удобрений в размере 43 млн долл. США, семян - 7 млн долл. США, средств защиты растений и животных -7 млн долл. США, топливно-энергетических ресурсов 59 млн долл. США.

Таким образом, ресурсообеспечение в сельском хозяйстве предопределяется устойчивостью рынка материальных ресурсов, готовностью аграриев в краткосрочном периоде приспособиться к различным изменениям (нормативно-правовой документации, роста цен и тарифов, дефицита определенных ресурсов и пр.) и успешно реализовать свою деятельность, а также наличием эффективных инструментов стабилизации.

В условиях отсутствия возможности достаточного потребления ресурсов целесообразно создание отдельной структуры по поддержанию сбалансированного производства сельскохозяйственной продукции с учетом разного положения устойчивости рынка материальных ресурсов, что предполагает координацию усилий всех субъектов в сфере АПК (сельскохозяйственные производители, организации пищевой промышленности и торговли, производители и поставщики материальных ресурсов, финансовые институты, грузоперевозчики и логистические центры).

\section{СПИСОК ЛИТЕРАТУРЫ (REFERENCES)}

Алферьев В.П. 2010. Экономическое регулирование рынка агроресурсов в условиях финансового кризиса. Техника и оборудование для села. № 1. С. 13-15. [Alfer'ev V.P. 2010. Economic regulation of agricultural resources in the conditions of financial crisis. Tekhnika $i$ oborudovanie dlya sela. No 1. PP. 13-15. (In Russ.)]

Алферьев В.П. 2013. Рынок ресурсов для села в условиях членства России в ВТО. АПК: экономика, управление. № 1. С. 48-54. [Alfer'ev V.P. 2013. Market of resources for rural areas in the context of Russia's WTO membership. APK: ekonomika, upravlenie. No 1. PP. 48-54. (In Russ.)]

Алферьев В.П., Павлова Г.С. 2010. Проблемы рынка средств производства и услуг в сельском хозяйстве. АПК: экономика и управление. № 11. C. 93-99. [Alfer'yev V.P., Pavlova G.S. 2010. Problems of the market of means of production and services in agriculture. APK: ekonomika, upravlenie. No 11. PP. 93-99. (In Russ.)]

Бельский В. 2019. Возможные решения по дальнейшему развитию обязательств в сфере государственной поддержки сельского хозяйства в ЕАЭС. Аграрная экономика. № 7. С. 3-10. [Belski V. 2019. Possible solutions for the further development of commitments related to state support of agriculture in the EAEU. Agrarnaya ekonomika. No 7. PP. 3-10. (In Russ.)]

Буць В.И., Таптунов Л.А. 2018. Теоретические и практические аспекты управления ресурсосбережением в агропромышленном производстве. Горки: Белорусская государственная сельскохозяйственная академия. [Buts V.I., Taptunov L.A. 2018. Theoretical and practical aspects of resource conservation management in agro-industrial production. Gorki: Belorusskaya gosudarstvennaya sel'skokhozyaystvennaya akademiya. (In Russ.)]

Гракун В. 2018. Приоритетные направления совершенствования агрохимического обеспечения сельскохозяйственных товаропроизводителей. Аграрная экономика. № 11. C. 18-26. [Grakun V. 2018. Improvement priority directions of agrochemical providing of agricultural producers. Agrarnaya ekonomika. No 11. PP. 18-26. (In Russ.)]

Гусаков В.Г. 2006. Основные объективные законы, закономерности и принципь рыночной экономики. Минск: Центр аграрной экономики Института экономики НАН Беларуси. [Gusakov V.G. 2006. Basic objective laws, laws and principles of the market economy. Minsk: Tsentr agrarnoy ekonomiki Instituta ekonomiki NAN Belarusi. (In Russ.)]

Гусаков В.Г. 2013. Как обеспечить устойчивость и конкурентоспособность национального АПК. Весці Наџыянальнай акадэміі навук Беларусі. Серыя аграрных навук. № 1. C. 9-22. [Gusakov V.G. 2013. How to ensure stability and competitiveness of the national agroindustrial complex. Vestsi Natsyyanal'nay akademii navuk Belarusi. Seryya agrarnykh navuk. No 1. PP. 9-22. (In Russ.)]

Гусаков В.Г., Шпак А.П. 2018. Агропромышленный комплекс Беларуси в условиях трансформационной экономики. Белорусский экономический журнал. № 4. C. 54-64. [Gusakov V.G., Shpak A.P. 2018. Agro-industrial complex of Belarus in the context of transformational economy. Belorusskiy ekonomicheskiy zhumal. No 4. РP. 54-64. (In Russ.)]

Казакевич И., Лазаревич И. 2018. Применение закупочных и товарных интервенций в сель- 
ском хозяйстве Беларуси как мера поддержания доходности производителей в условиях международной экономической интеграции. Аграрная экономика. № 3. C. 19-30. [Kazakevich I., Lazarevich I. 2018. The use of procurement and commodity interventions in the agricultural sector of Belarus as a measure of maintaining the profitability of producers in the context of international economic integration. Agrarnaya ekonomika. No 3. PP. 1930. (In Russ.)]

Киреенко Н.В., Горбатовский А.В., Горбатовская О.Н., Довнар Л.И. 2020. Внешние условия и факторы функционирования отраслей животноводства Республики Беларусь. Белорусский экономический журнал. № 2. С. 96-108. [Kireyenka N.V., Gorbatovski A.V., Harbatouskaya A.N., Dounar L.I. 2020. External conditions and factors for livestock sector operations in the Republic of Belarus. Belorusskiy ekonomicheskiy zhurnal. No 2. PP. 96108. (In Russ.)]

Корецкий П.Б. 2017. Обеспечение хозяйствующих субъектов аграрной сферы материальными ресурсами и условия доступа к ним. Becmник Воронежского государственного аграрного университета. № 1. C. 188-198. [Koretskiy P.B. 2017. Material resources supply to economic entities of the agrarian sphere and their access conditions. Vestnik Voronezhskogo gosudarstvennogo agrarnogo universiteta. No 1. PP. 188-198. (In Russ.)]

Лазаревич И.М., Микулич А.В., Тетеркина А.М., Пашкевич Е.И., Антонова А.В. 2018. Методические рекомендации по разработке ценовой поддержки аграрного сектора в соответствии с международными принципами. Научные принципь регулирования развития АПК: предложения и механизмы реализации. С. 96-104. [Lazarevich I.M., Mikulich A.V., Teterkina A.M., Pashkevich E.I., Antonova A.V. 2018. Methodological recommendations for developing price support for the agricultural sector in accordance with international principles. Nauchnye printsipy regulirovaniya razvitiya $A P K$ : predlozheniya $i$ mekhanizmy realizatsii. PP. 96-104. (In Russ.)]

Лукашев Н.И. 2009. Развитие рынка средств для сельского хозяйства. Техника и оборудование для села. № 11. С. 26-29. [Lukashov N.I. 2009. The development of agricultural means of production markets. Tekhnika i oborudovanie dlya sela. No 11. PP. 26-29. (In Russ.)]

Макрак C.B. 2019. Научные основы совершенствования системы управления материальноденежными ресурсами при производстве сельскохозяйственной продукции. Весці Нащыянальнай акадэміі навук Беларусі. Серыя аграрных навук. № 2. C. 135-150. [Makrak S.V. 2019. Scientific bases of the control system improvement of material and monetary resources by agricultural production. Vestsi Natsyyanal'nay akademii navuk Belarusi. Seryya agrarnykh navuk. No 2. PP. 135-150. (In Russ.)]

Мальцева В.A. 2015. Государственная поддержка сельского хозяйства в зарубежных странах: эволющия теории и практики реализации. Екатеринбург: Издательство УМЦ УПИ. 228 с. [Maltseva V.A. 2015. State support for agriculture in foreign countries: Evolution of theory and practice. Ekaterinburg: Izdatel'stvo UMTs UPI. 228 p. (In Russ.)]

Маслова В.В., Чекалин В.С., Авдеев М.В. 2019. Развитие сельского хозяйства в условиях импортозамещения. Вестник Российской академии наук. T. 89. № 10. C. 1024-1032. [Maslova V.V., Chekalin V.S., Avdeev M.V. 2019. Development of agriculture in the context of import substitution. Vestnik Rossiyskoy akademii nauk. Vol. 89. No 10. PP. 1024-1032. (In Russ.)]

Тетеркина А., Строгий В. 2017. Развитие механизма закупочных и товарных интервенций в сельском хозяйстве Республики Беларусь. Аграрная экономика. № 4. С. 39-44. [Tsiatsiorkina A., Strohi V. 2017. Mechanism development of purchasing and commodity interventions in agricultural of the Republic of Belarus. No 4. PP. 39-44. (In Russ.)]

Шпак А.П. 2017. Приоритетные направления повышения эффективности и устойчивости развития аграрного сектора Республики Беларусь. Экономика АПК. № 6. С. 26-32. [Shpak A. 2017. Priority directions for increasing of the efficiency and sustainability of development of the AIC of Belarus. Ekonomika APK. No 6. PP. 26-32. (In Russ.)]

Шпак А. 2018. В аграрной отрасли нужны системные решения. Аграрная экономика. № 3. C. 69-74. [Shpak A. 2018. The agricultural sector needs system solutions. Agramaya ekonomika. No 3. PP. 69-74. (In Russ.)] 
In citation: Belorusskiy Ekonomicheskiy zhurnal. 2021. No 1. PP. 87-100.

Belarusian Economic Journal. 2021. No 1. PP. 87-100.

\title{
HOW TO ACHIEVE SUSTAINABILITY IN THE MATERIAL AGRICULTURAL RESOURCES MARKET AS PART OF RESOURCE PROVISION
}

\begin{abstract}
Svetlana Makrak ${ }^{1}$
Author affiliation: 1 The Republican Scientific Unitary Enterprise «The Institute of System Research in Agroindustrial Complex of NAS of Belarus» (Minsk, Belarus).

Corresponding author: Svetlana Makrak (makraksv@inbox.ru).

ABSTRACT. The article provides the definition of sustainability in the material resources market for agriculture. We studied certain indicators of material resources market conditions between 2000-2019. Thus, a set of measures and tools to enable sufficient resource provision of agricultural production is designed. Approaches to form the mechanism of functioning of the public operator for balanced agricultural production are revealed; ways to create Funding Resources for Farmers and algorithms for its allocation are designated. Assessment methodology of sustainability in the material resources market for agriculture is
\end{abstract} proposed.

KEYWORDS: material resources, agriculture, resource provision, material resources market, assessment methodology, efficiency.

JEL-code: Q10, Q11, Q12, Q17, Q18.

DOI: $10.46782 / 1818-4510-2021-1-87-100$

Received 29.09.2020 